\title{
Irenaeus vs. the Valentinians: Toward a Rethinking of Patristic Exegetical Origins
}

\section{LEWIS AYRES}

\author{
For Richard and Roberta Bondi on the occasion of their \\ 138th birthday. Ad multos annos!
}

An under-studied dimension of Irenaeus's exegetical practice is his extensive use of Hellenistic literary-critical techniques. He couples this usage with a consistent claim that the meaning of texts should primarily be established by attending to the "clear" or "manifest" sense of terms and expressions. Irenaeus's practice culminates a gradual and deepening engagement with these techniques apparent in earlier Christian texts, but the suddenness and striking quality of his advance is best explained by seeing him as reacting to the Valentinian production of commentary literature that claims the cultural capital of ancient literary-critical techniques to justify reading the texts of the "New Testament" as enigmatic ciphers for Valentinian myths. Irenaeus responds by making a distinct claim on the same cultural capital-one that utilizes an established anti-allegorical rhetoric - to justify his own practice. Understanding Irenaeus's particular adaptation of ancient literary-critical practice provides a deeper context for considering his emphasis on reading in the light of the regula veritatis. In so doing he becomes a foundational figure in shaping the exegetical practice so central to early Christianity in the centuries that follow.

An earlier version of this paper was presented to audiences at the Universities of Edinburgh and Durham. I am grateful for the very helpful discussion that followed on both occasions. I would like to thank Robert Wilken, Antony Briggman and the two anonymous JECS readers for their helpful critiques of the penultimate version. This paper and the project of which it is part emerged from a doctoral seminar on early Christian exegesis taught with Gail O'Day at Emory over a number of years. I am thus also deeply grateful to Gail and to the students who participated. 


\section{INTRODUCTION}

The reader of my title might fairly ask a simple question: how can we speak of the "origins" of patristic exegesis in the late second century? Surely the origins lie in the exegetical practice of those whom modern scholars term the "apostolic fathers," and those who wrote the texts that became the "New Testament," if not further back in the exegetical practice of Second Temple Judaism? And, in important ways, this is true. Nevertheless, I offer this paper as the first step in a project that will show how the late second century constitutes a distinct "origin" all of its own.

One of the most striking evolutions in Christian thought and practice between the middle of the second century and the middle of the third is the rise to prominence of a Christian exegesis that is heavily dependent on the techniques of literary analysis honed within the developing disciplines of grammar and rhetoric. ${ }^{1}$ Christian exegetes make use of not only of the techniques but also the technical vocabulary of their nonChristian models, claiming for themselves the cultural capital accruing to this foundation of Hellenistic (and Roman) literary culture. ${ }^{2}$ As Bernhard Neuschäfer's seminal Origenes als Philologe has shown, these techniques are apparent particularly clearly in the work of Origen. ${ }^{3}$ In the decades and centuries that follow the same techniques are foundational for almost all Christian interpreters. Existing scholarship generally assumes that, as the stability and financial resources of their communities grew, Christian exegetes naturally and inevitably made use of the reading techniques that

1. When I speak about techniques of "literary-critical analysis," I refer to a broad range of practices that are evident in Greek commentary literature and scholia, as well as in en passant discussion of texts in other literary genres. In the imperial period these techniques were partially inculcated by grammarians and teachers of rhetoric, but also used and developed in a variety of forms by philosophical writers and commentators, as well as by medical writers, historians and others.

2. We should ask how the rise to prominence of these techniques is intertwined with the significant developments in the use of an increasingly fixed canon of Christian Scriptures that occurred during the second century. In particular, did the conscious use by anti-Valentinain writers of techniques that emphasized interpreting terms within a fixed text bolster and shape conceptions of the scriptural canon? These questions are, however, beyond the bounds of my concern in this essay.

3. Bernhardt Neuschäfer, Origenes als Philologe, 2 vols. (Basel: Friedrich Reinhardt, 1987). To the material assembled there should be added Andrea Villani, "Origenes als Schriftsteller: ein Beitrag zu seiner Verwendung von Prosopopoiie, mit einigen Beobachtungen über die prosopologische Exegese," Adamantius 14 (2008): 130-50. For other relevant literature on Origen see the various essays and attendant bibliographies in H. Pietras and S. Kaczmarek, eds., Origeniana Decima: Origen as Writer (Leuven: Brepols, 2011). 
were the foundations of Greek and Roman literary culture. ${ }^{4}$ While such an explanation probably contains much truth, the wider project of which this essay is part will argue that polemical struggle with Valentinain exegesis provided the stimulus for the wholesale adoption of these techniques in the period between 180 and 200, and enables us to account for the manner in which proto-orthodox writers adapted ancient exegetical culture to their own ends. This essay considers aspects of just one-although a pivotal "one" —of the figures who will need to be encompassed by such a wide-ranging argument if it is to be fully persuasive-Irenaeus of Lyons.

\section{“. . IN PARABLES AND ENIGMAS" ${ }^{5}$}

Sometime during the third quarter of the second century, Valentinian writers began to produce commentaries on some of the texts that were gradually becoming the "New Testament" that treat those texts as enigmatic, as hinting at Valentinian cosmogonies and accounts of the Savior's work. ${ }^{6}$ The importance of these Valentinian texts becomes apparent when we remember that Irenaeus introduces his Against Heresies (most

4. Frances Young, in her Biblical Exegesis and the Formation of Christian Culture (Cambridge: Cambridge University Press, 1997), 49-76, offers a particularly sophisticated version of this account, suggesting that the fundamental shift occurred when Christians came to see the Scriptures as an alternative body of "classics." Doing so involved the claim that all other learning was superseded and brought with it an almost inevitable application of traditional literary-critical tools.

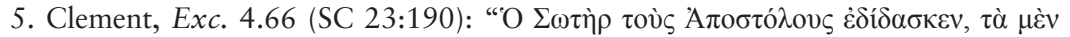

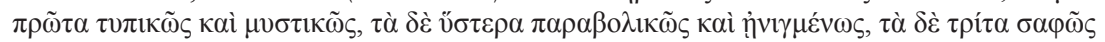

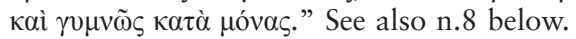

6. When I use the term "Valentinian" I do so in the light of Christoph Markschies's ingenious suggestion that Valentinians may have self-identified as a philosophical school, but that, if they did so, this only serves to reinforce the point that they would have found no problem in so identifying and containing considerable diversity and undergoing considerable shifts in approach over a few generations. See Christoph Markschies, "Valentinian Gnosticism: Toward the Anatomy of a School," John B. Turner and Anne McGuire, The Nag Hammadi Library After Fifty Years (Leiden: Brill, 1997), 401-38. On Valentinian doctrine see the magisterial Einar Thomassen, The Spiritual Seed. The Church of the 'Valentinians' (Leiden: Brill, 2006) and Ismo Dunderberg, Beyond Gnosticism. Myth, Lifestyle and Society in the School of Valentinus (New York: Columbia University Press, 2008). Unfortunately, neither Thomassen nor Dunderberg discuss Valentinian exegetical technique (though see the helpful discussion of Valentinain "secrecy" at Dunderberg, 191-96). The literature here is of course extensive: but for those familiar with the idea that there were eastern and western schools of "Valentinians" it is worth attending to the caveats of Joel Kalvesmaki, "Italian versus Eastern Valentinianism?," VC 62 (2008): 79-89. On Valentinus himself, see also n.46 below. 
likely composed during the reign of Zephyrinus, c.175-89) by telling us that his opponents are those who "falsify the words of the Lord," those

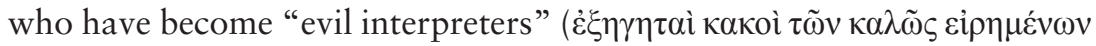

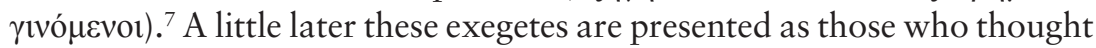
that, because all are not capable of grasping the truth, the one called Savior taught by means of parables ( $\delta$ iò $\pi \alpha \rho \alpha \beta o \lambda \tilde{\omega} v) .{ }^{8}$ While many texts and groups will be gradually drawn into Irenaeus's net, his point of departure is a quite precise set of exegetes.

Our bishop then famously quotes an example, providing one important witness to this Valentinian exegetical project. ${ }^{9}$ For our purposes two extracts from that quotation will suffice:

John, the disciple of the Lord, wishing to narrate the origin of all things

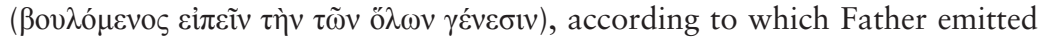

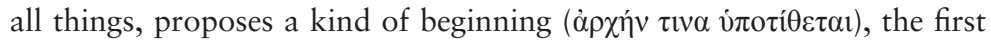
thing begotten by Father, whom he called Son and Only-begotten God, by whom Father emitted all things as though a "seed." They say that Word was emitted by this Only-begotten and in him was emitted the whole substance of the Aeons whom Word himself formed later. Since, then, he speaks of the first origin [of things], he does well to start his doctrine with the Beginning, that is, with the Son and the Word. He writes as follows: "In the beginning was the Word, and the Word was with God, and the Word was God. He was in the beginning with God.” First, he distinguishes

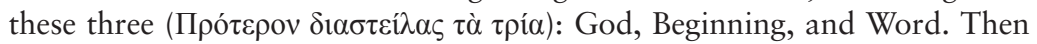
he unites them in order to demonstrate the emission of each one singly

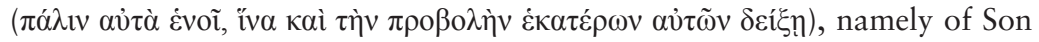
and Word, and the union of Son to Word, and of both to Father. For the Beginning is in Father and from Father; but Word is in Beginning and from Beginning. Therefore, he said well: "In the beginning was the Word," for he was in Son. "And the Word was with God," for he was also Beginning. ${ }^{10}$ ... For when he continues, "And the Life was the light of men," though he now speaks of men, he indicated also Church by a homonym, so that by the one name he might manifest the union of the conjugal couple

7. Adv. Haer. praef. 1 (SC 264:18). Cf. Adv. Haer. 2. praef.

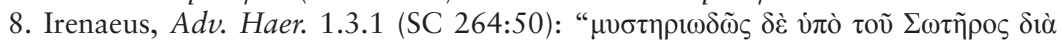

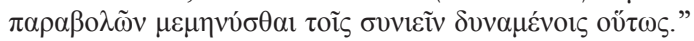

9. I say "this" exegetical project to differentiate it from others represented by such texts as The Gospel of Truth. The elements of "rewritten scripture" included there and elsewhere are beyond my purview here.

10. Irenaeus, Adv. Haer. 1.8.5 (SC 264:129-30; trans. ACW 55:44). Throughout I have used the translations of Adv. Haer. 1-3 in ACW 55 (trans. Unger and Dillon), 64 (trans. Unger and Dillon) and 65 (trans. Unger and Steenberg); I have made a number of unnoted alterations. 


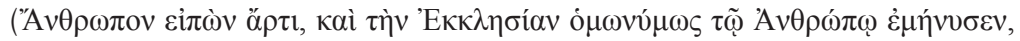

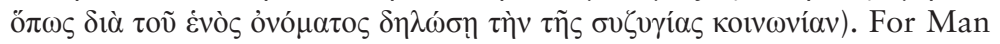
and Church spring from Word and Life. Besides, he called Life the Light of Men, because they were enlightened by her. Paul says the same thing, "For anything that becomes visible is light" (Eph 5.14). Since, therefore, Life is manifested, and gave birth to Man and Church, she is called their light. By these words, then, John clearly manifested among other things, the second

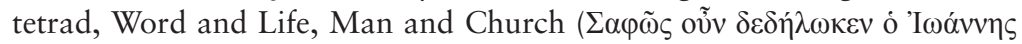

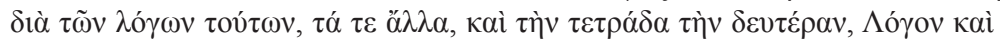

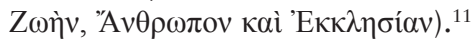

Allow me to locate this style of commentary with two brief discussions:

1. Peter Struck's Birth of the Symbol de-centers the traditional focus of scholars in early Christian studies on the terms "allegory" and "type" and stimulates a broader consideration of the contexts within which Christian

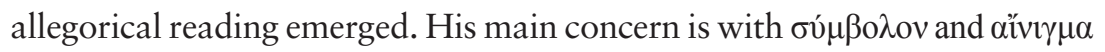
as terms central to a broad semantic field concerning the interpretation of that which is hidden. ${ }^{12}$ Struck comments especially on the interplay between divinatory notions of the symbolic and literary notions. In many ancient traditions, Struck argues, $\sigma 0 ́ \mu \beta 0 \lambda o v$ and $\alpha$ ív $\gamma \mu \alpha$ (alongside a range of other terms) reveal a similar "ideology of exclusiveness," both are "born

11. Adv. Haer. 1.8.5 (SC 264:132-34). Questions of authorship here are complex. The Latin, but not the Greek as it survives in Epiphanius (Pan. 31.27.11), conclude the quotation with Et Ptolemaeus quidem ita. Many scholars took this to reveal the true authorship (eg. see the note at SC 263:218); more recently (and convincingly) Christoph Markschies, "New Research on Ptolemaeus Gnosticus," Zeitschrift für antikes Christentum 4 (2000): 249-53 has argued that the ascription is an addition of the Latin translator and that we can attribute the quotation only to disciples of Ptolemy. I know of no scholarship that attempts to analyze the reading techniques used in this text.

12. At this point it will be helpful to note that the Valentinian texts which survive do not use a consistent terminology for their exegesis. The text quoted by Irenaeus includes no technical terminology, though a little earlier he tells us that those whom

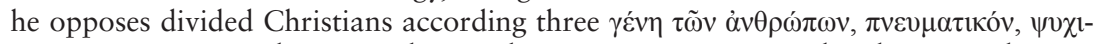

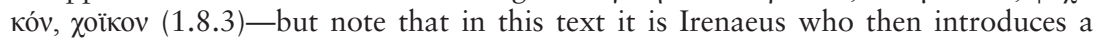
reference to 1 Cor 2.14-15. Heracleon twice speaks of interpretation under the divi-

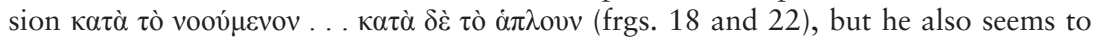

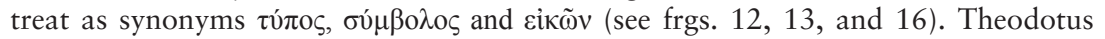

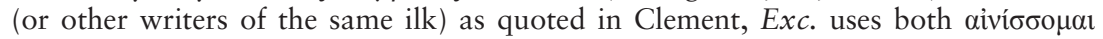
(51.2 and 67.4) and $\dot{\alpha} \lambda \lambda \eta \gamma о \rho \varepsilon \omega$ (56.5 and 62.2) as well as the terminology noted above, n.4. In Ep. Flor. Ptolemy divides the Law into categories, the third of which

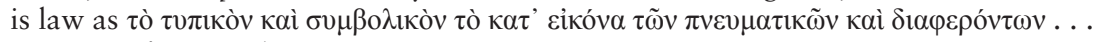
(33.5.2. Cf. 5.9 and 6.4). 
from the power of the secret." ${ }^{13}$ From this broad conceptual matrix many different notions of the "allegorical" emerge; that which sees "allegory" as a particular figure of speech is not in any way normative, and emerges as an attempt to police broader and more diffuse traditions. It is against the background of this broader tradition that we must locate the particular emergence of the Valentinian commentaries that are our concern.

That these commentaries emerge in the second century is of considerable significance. French scholarship on the history of the allegorical has traditionally presented the first two centuries of the imperial period as a transitional era between early Stoic allegorists, who treated ancient mythological material (and the Homeric corpus) as inadvertently hiding cosmological and metaphysical knowledge that could now be stated clearly, and the Neoplatonic allegorists of the late third century on, for whom Homer (and other texts and rituals) speak of Gods, of the intelligible, and of the path through the latter toward the former. ${ }^{14}$ It is in this transitional period that we find, for example, Plutarch both criticizing Stoic allegory as impious, as a lazy practice for those who should be learning attention to the character of literary construction, and yet also celebrating allegorical readings of pious ritual and myth which present those actions and texts as hiding truths about the divine. ${ }^{15}$

George Boys-Stones offers us a few more lines for this brief sketch of the period when he argues that while traditional Stoic allegory survived into this period, we see also the emergence of a later Stoic model, far closer to that which we find in Neoplatonic and Christian authors, in which it is accepted that the wise, from the earliest days of humanity, have chosen to hide their insight from all except those with the skill to interpret. ${ }^{16}$ Toward

13. Peter T. Struck, Birth of the Symbol. Ancient Readers at the Limits of Their Texts (Princeton: Princeton University Press, 2004), 179. Struck's account should be required reading for students of non-literal modes of reading in antiquity. His particular reflections on the transitions apparent in the period between 300 B.C.E. and 200 C.E. are to be found in chaps. 3-5.

14. Seminally, Jean Pépin, Mythe et allégorie. Les origines grecques et les contestations judéo-chrétiennes (Paris: Aubier, 1958) and Félix Buffière, Les Mythes d'Homère et la pensée grecque (Paris: Les Belles Lettres, 1956). For a recent iteration see Luc Brisson, How Philosophers Saved Myths: Allegorical Interpretation and Classical Mythology, trans. Catherine Tihanyi (Chicago: University of Chicago Press, 2004).

15. For Plutarch's critique of allegorical readings of Homer see below n.84. For his celebration of a rather different allegory see Isis. 354B-D.

16. See G. R. Boys-Stones, "The Stoics' Two Types of Allegory," in Metaphor, Allegory and the Classical Tradition, ed. G. R. Boys-Stones (Oxford: Oxford University Press, 2003), and his earlier discussion in Post-Hellenistic Philosophy (Oxford: Oxford University Press, 2001), chaps. 1-3. 
the end of the second century we can likely also locate Numenius's allegorical reading of a wide variety of ancient texts (including both Plato and the Hebrew Scriptures) as alluding to a common hidden cosmology and anagogy. ${ }^{17}$ This last addition to the list may be of particular importance, given the manner in which so much of the Valentinian cosmology seems to echo aspects of Platonic doctrine. Thus, the Valentinian project with which we are concerned flourished alongside other hermeneutical visions that saw particular texts as intentionally enigmatic, hinting at truths about the divine that the expert and initiated could uncover. ${ }^{18}$

2. The second conversation that helps to locate this text concerns its use of ancient techniques of literary analysis to structure and justify its reading. Note some features of this text that find extensive parallels in many kinds of non-Valentinian literary commentary. First, the interpreter identifies a traditional type of ambiguity-homonymity-in the text as a point of departure for showing how John is best read as subtly indicating the Valentinian myth. ${ }^{19}$ The interpreter then gives us a reason for John's use of this homonym, and the Valentinian myth provides part of that reason: it is to indicate that "Man and Church spring from Word and Life." Second, this interpretation is further bolstered by paralleling

17. The most important fragment in this regard is frg. 30 , the one text where we have a clear example of Numenius's use of the Hebrew Scriptures. Numenius is reported by Porphyry as linking Genesis's presentation of the divine pneuma as being "borne upon the waters," to Egyptian presentations of the Sun riding on a ship. See Robert Lamberton, Homer the Theologian. Neoplatonist Allegorical Reading and the Growth of the Epic Tradition (Berkeley: University of California Press, 1989), 54-77; M. Frede, "Numenius," in ANRW II.36.2, ed. W. Haase (Berlin and New York: de Gruyter, 1987), 1034-75; Édouard Des Places "Numénius et la Bible," Études Platoniciennes 1929-1979 (Leiden: Brill, 1981), 310-15.

18. I have purposefully not discussed Philo in this paper, because of the complex manner in which his "allegorical" reading relates to prior adoption of Alexandrian literary-critical practice. Examination of his significance as a parallel to the Christian developments I explore here must await another opportunity. For a wonderful discussion which reveals many of the avenues that discussion must explore see Maren Niehoff, Jewish Exegesis and Homeric Scholarship in Alexandria (Cambridge: Cambridge University Press, 2011).

19. E.g. Quintilian's discussion of the different types of ambiguity in texts, of which

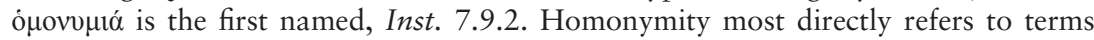
that have multiple commonly accepted meanings, but Quintilian goes on to state that this form of ambiguity occurs plurimis modis, and to give the example of an ambiguity in a will in which a name is shared by more than one possible beneficiary, or in which it is not clear precisely what bequest is included under a particular term. In our case the exegete seems to be claiming that John's use of "man" creates a homonym. 
John and Paul; "the Life was the light of men" parallels "for anything that becomes visible is light" (cf. Eph 5.13). "Life" can be said to be the "light of men" by explaining that life makes manifest or "enlightens," the text from Ephesians providing the explanation for John's choice of vocabulary. Here one of the most famous principles of literary criticism in the imperial period has been used, the principle that an author should be interpreted from his own writings (Homerum ex Homero)—and, interestingly, the Valentinian commentator treats John's gospel and Ephesians as part of a unified whole. ${ }^{20}$

There are also wider principles visible here. Kathy Eden argues that, in both rhetorical and grammatical traditions, good interpretation involved showing how the various parts and subdivisions of a text constituted a unified whole. ${ }^{21}$ In many cases revealing this appropriate combination of parts involved arguing for an author's skill in making appropriate choices in textual composition. At the beginning of this text the author again follows standard practice in beginning an analysis of the Johannine prologue by identifying its overall hypothesis ("wishing to narrate the origin of all things"). Then, interpreting what follows in the light of this bypothesis, our Valentinian interpreter notes the elegance of speaking first of the

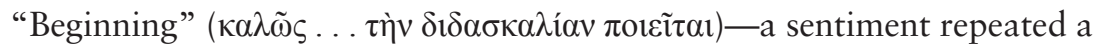

20. For discussion of this key principle see Christoph Schäublin, "Homerum ex Homero," Museum Helveticum 34 (1977): 221-27; Jaap Mansfeld, Prolegomena. Questions to be Settled Before the Study of an Author, or a Text (Leiden: Brill, 1994), 177-79, 204-5. For a particularly clear statement of the principle (here concerning the interpretation of ambiguities in wills) see Cicero, Inv. 2. 40.117 (Guy Achard, ed., Cicéron. De l'invention [Paris Les Belles Lettres, 1994], 204): “. . . quae autem ex omni considerata scriptura perspicua fiant, haec ambigua non oportere existimare. Deinde, qua in sententia scriptor fuerit, ex ceteris eius scriptis et ex factis, dictis, animo atque vita eius sumi oportebit, et eam ipsam scripturam. . . ." For a statement directly contemporary to the texts that are the focus of this paper see Galen's commentaries on the Hippocratic corpus. In the extensive preface to his commentary on the De fracturis, for example, we are told that the exegete must make clear the unclear, identifying the meaning of obscure terms and providing expert information necessary for understanding expressions otherwise unclear to the uninitiated. See C. G. Kühn, Klaudiou Galènou hapanta. C. Galeni opera omnia, Medicorum Graecoum Opera Quae Exstant, vol. 18.2 (Leipzig: C. Cnoblochii, 1829), 318-22. The same theme is also seen in the case not of the author, but of the interpreter of a text. Eg. Plutarch, De aud. poet. $22 \mathrm{~F}$ emphasizes the importance of taking the signification of a term differently in different contexts so as to produce a suitable interpretation; Mansfeld, Prolegomena, 155-61 shows Galen conceiving of exegesis itself as naming a creative process.

21. Kathy Eden, Hermeneutics and the Rhetorical Tradition (New Haven and London: Yale University Press, 1997), 30-40. See Quintilian, Inst. 7.10.16-17 for emphasis on the harmonious ordering of discrete parts. 
little later at the end of commenting on this verse ( $\kappa \alpha \lambda \tilde{\omega} \varsigma$ oṽv عĩ $\pi \varepsilon v)$. To the appropriately learned interpreter, a precise message is revealed through an elegantly chosen series of signals; the commentator values highly the traditional compositional virtue of "appropriateness" (aptum or $\tau$ ò $\pi \rho \varepsilon ́ \pi o v) .{ }^{22}$

The literary-critical techniques invoked here have a long pedigree, and the manner in which those techniques were contested by those with very different perceptions about textual meaning is perhaps best grasped through narrating two different possible histories of their use. The first might begin with the precepts of Aristotle in Poetics 25 (and their instantiation in the now largely lost Homeric Problems). These general precepts were developed in Alexandria into a complex practice of textual analysis by, and then in the wake of, such figures as Aristarchus. ${ }^{23}$ The emergence of "grammar" as a distinct educational discipline between the late second century B.C.E. and first century C.E. helped to fix a particular set of reading techniques as foundational for virtually all traditions of literary commentary (grammatical, rhetorical, legal, philosophical interpreters all adapted their own sets) in the imperial and late antique periods. One could fairly say that the central concern of this tradition-especially if we can see an Aristotelian emphasis in the work of Aristarchus-was the attempt to elucidate the structure of the text and to compile information necessary to understand references, allusions and compositional preferences. Throughout, the application of these techniques to valued authors also involved revealing the author of a text as a practitioner of the skilled and "appropriate" choice. At the same time, this tradition shows a suspicion of the enigmatic and parabolic. For example, it frequently treated

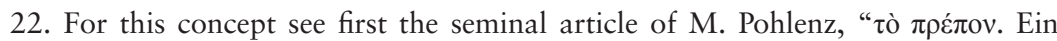
Beitrag zur Geschichte des greichischen Geistes," in Kleine Schriften, vol. 1, ed. Heinrich Dörrie (Hildesheim: George Olms), 100-139. To compare the importance of the concept in both composition of texts and the orator's work cf. Dionysius of Halicarnassus, De comp. 20 and 6-7; Aristotle, Rhet. 3.7; Cicero, Or. 70-72, 123. For further texts whose primary consideration is rhetoric, but which also frequently speak of the concept as a feature of textual structure see Heinrich Lausberg, Handbuch der literarischen Rhetorik (Munich: Max Hueber Verlag, 1973), \$1055-62, and for texts relating to errors against propriety see $\$ 1074-77$. It is a great pity that the excellent study of Helen DeWitt, "Quo virtus?: The Concept of Propriety in Ancient Literary Criticism" (DPhil dissertation, Oxford, 1987), remains unpublished.

23. For a reading of literary tradition in Alexandria as drawing on Aristotelian tradition see P. M. Fraser, Ptolemaic Alexandria, 2 vols. (Oxford: Oxford University Press, 1972), 1:447-79. One of the very best resources for studying the character of Alexandrian Homeric commentary is now René Nünlist's The Ancient Critic at Work: Terms and Concepts of Literary Criticism in Greek Scholia (Cambridge: Cambridge University Press, 2009). 
seemingly inappropriate statements or actions in Homer as the product of his rhetorical need to present life accurately, to give people fully rounded characters and to make the plot convincing (and on occasions as appropriately excised or marked as inauthentic). For many in this tradition allegory is only a limited literary trope. ${ }^{24}$

But a second story must accompany this first. Many of the techniques adapted by Aristotle and by the Alexandrian commentary tradition were consistently used by those who promoted varieties of enigmatic and allegorical reading and likely pre-date Aristotelian usage. Thus, the (possibly) mid-fifth century B.C.E. author of the Dervenni papyrus sees Orpheus as composing poems that hide their true meaning throughout. But exploration of homonymity and etymology enables much of the author's exegesis; through such techniques cosmological details are introduced as explanatory, and the mode of composition is shown by such techniques to be "apt." ${ }^{25}$ The little that we have from Crates of Mallos shows us an exegete of the second century в.C.E. using grammatical techniques in support of allegorical readings. ${ }^{26}$ The Homeric Questions of Heraclitus (first-second century C.E.) speak of allegory as a trope, and yet also insist that through the whole of his text Homer the great hierophant nurtures us in different ways throughout our lives. ${ }^{27}$ Etymological explanation (frequently using homonymity as a point of departure) is central in this text, but Heraclitus also comments on a number of other literary devices that he sees as revealing the presence and nature of Homer's allegory. ${ }^{28}$ Throughout, Heraclitus

24. See eg. the famous comments of Quintilian, Inst. 8.6.52: "Sed allegoria quae est obscurior 'aenigma' dicitur, vitium meo quidem iudicio si quidem dicere virtus. . .."

25. For the text see Richard Janko "The Derveni Papyrus: An Interim Text," Zeitschrift für Papyrologie und Epigraphik 141 (2002): 1-62; Janko, "The Derveni Papyrus (Diagoras of Melos, Apopyrgizontes Logoi?): A New Translation," Classical Philology 96 (2001): 1-32. The literature on the papyrus is considerable, for brief introductions to some current debates see also André Laks, "Between Religion and Philosophy: The Function of Allegory in the Derveni Papyrus," Phronesis 42 (1997): 121-42; Gábor Betegh, "Exegesis in the Dervenni Papyrus," in Philosophy, Science and Exegesis in Greek, Arabic and Latin Commentaries, vol. 1, eds. Peter Adamson et al. (London: Institute of Classical Studies, 2004), 37-50. On Orpheus's purpose see col. 8; for etymology and homonymity see 9-11; for the introduction of scientific material as explanation of Orpheus's true intent see 10-16.

26. James I. Porter, "Hermeneutic Lines and Circles: Aristarchus and Crates on the Exegesis of Homer," Homer's Ancient Readers, eds. Robert Lamberton and John J. Kearney (Princeton NJ: Princeton University Press, 1992), 67-114.

27. Heraclitus, Quaest. 6.1 and then 1.5-7; cf. 53, 76.

28. For etymology see Heraclitus, Quaest. 7, 31, esp. 44. For commentary on other features of the text see, eg., Heraclitus's reading of Dionysius as an allegory through identifying "mad" as a descriptor as that type of metonymy which indicates 
identifies these literary figures as a means of showing that the text is intentionally allegorical (and hence as a justification for introducing "scientific" speculations he takes to be plausible), and also as a means of showing that the allegory has been produced by a master craftsman and that, hence, it reveals itself only to the skilled exegete. The Pseudo-Plutarchan Life of Homer, probably written by someone with strongly grammatical interests in the later years of the second or the early years of the third century C.E., provides us with further examples of these reading techniques, and further examples of emphasis on celebrating Homer's compositional skill. ${ }^{29}$ The fragments of Numenius provide us with little clear evidence that he also made use of the same smorgasbord of techniques, but Porphyry's On the Cave of the Nymphs and the fragments of his Homeric Questions show the centrality of such techniques in the first flowering of Neoplatonic allegory during the second half of the third century, and make it all the more likely that Numenius (whose exegesis Porphyry celebrates) stood in the same commentary tradition. ${ }^{30}$ My aim in listing these authors is not to play down differences between their styles of enigmatic reading, but to show how consistently many of the techniques of literary analysis honed in Alexandria were also used by exegetes of the enigmatic from the fifth century B.C.E. down through the period considered in this essay. Indeed, some of these figures do not only parallel Alexandrian textual practice, but show significant dependence on both Alexandrian commentary and the developing institution of the professional grammarian-this is especially true of Heraclitus and the author of the Pseudo-Plutarchan Essay. The reading techniques used by allegorical and non-allegorical readers are thus significantly contested; pro- and anti-allegorical exegetes claim

cause by effect (35). See also Heraclitus's identification of Ares as standing for war by commenting on the adjectives Homer attaches to the name; in common parlance all signify war more than a God (31-2).

29. See Ps. Plutarch, vit. Hom. 6 and 92 for description of Homer's use of the mythical. For examples of the grammarian's interest in Homeric diction see 8-13; for celebration of Homer's use of tropes see the extensive discussion of 16-71. For examples of the ways in which literary-critical practices are used to justify allegorical readings see eg. 101, where Homer's penchant for using plural nouns for singular realities justifies taking $\pi \alpha ́ v \tau \alpha$ to signify a unified universe; or 127 , where our author comments on Homer's patterns of consistent word usage to justify reading him as possessing a consistent doctrine of $\pi v \varepsilon \tilde{v} \mu \alpha$.

30. For the relationship between these two works of Porphyry see Lamberton, Homer the Theologian, 108-33; the restored introduction of Porphyry's works as edited by A. R. Sodano, Questionum Homericarum, liber I (Naples: Gianni, 1970). For Numenius see above, n.17. 
the cultural capital accruing to such techniques in order to locate themselves as skilled and their exegesis as plausible. Thus, it should not surprise us that the Valentinian authors considered here made careful use of such techniques in analyzing texts and justifying their exegetical practice. Treating the texts on which they commentated as wholly or significantly enigmatic may have seemed to them to follow Christ's own injunctions; using these techniques on those texts shows them also embedded deep in Greek literary tradition. ${ }^{31}$

\section{THE VALENTINIAN INNOVATION}

Nowhere else does Irenaeus provide us with a similarly extensive quotation from a Valentinian commentary. ${ }^{32}$ In terms of exegetical practice, the closest parallel to the commentary Irenaeus quotes are the surviving fragments of Heracleon's commentary on John. Ansgar Wucherpfennig has already offered important discussion of Heracleon's indebtedness to Hellenistic literary criticism, and so here I will offer brief comment on only two fragments to show the continuity between Heracleon and the text quoted by Irenaeus. ${ }^{33}$ In fragment 1 , commenting on John 1.3, we find:

31. See e.g. Matt 13.12-14 (and parallels).

32. The other examples he provides are usually torn from their original context. See eg. Adv. Haer. 1.8.2-4 and 1.3.1-5. Even here, though, we may learn something. For example, the striking interpretation of Christ's invocation of Psalm 22(21) from the cross that Irenaeus reports at 1.8.2 shows no interest in interpreting Christ's words in the context of the remainder of the Psalm. Can this be trusted as revealing with a little more precision some of the ways in which Valentinian exegetes felt free to ignore inter-textual reference within Christian Scriptures because of their strong sense of possessing a better key to the meaning at which Christ hints?

33. Ansgar Wucherpfennig, Heracleon Philologus: Gnostische Johannesexegese im zweiten Jahrhundert (Tübingen: J. C. B. Mohr, 2002). Wucherpfennig, I think, unfairly denigrates Origen's account of Heracleon's teaching, but he places Heracleon's method firmly in the context of ancient commentary. See pp. 48-103 for his initial discussion (with ref. to frgs. 11-16) and pp. 372-82 for summary of his argument. On Heracleon more widely see the wisely cautious comments of C. P. Bammel, "Herakleon," Theologische Realenzyklopädie 10:54-57 and the summary account of Einar Thomassen, "Heracleon," in The Legacy of John: Second-Century Reception of the Fourth Gospel, ed. Tuomas Rasimus (Leiden: Brill, 2010), 173-210. It is noticeable that other studies of his exegesis neglect Heracleon's actual technique. See eg. J.-M. Poffet, Le méthode exégetique d'Héracléon et d'Origène, commentateurs de Jn 4: Jésus, la Samaritaine et les Samaritaines (Fribourg: Éditions Universitaires, 1985); J.-D. Kaestli, "L'Exégèse valentinienne du quatrième évangile," in Le Communauté johannique et son histoire: Le trajectoire de l'évangile de Jean aux des premiers siècles, eds. J.-D. Kaestli et al. (Geneva: Labor et Fides, 1990), 323-50; Elaine Pagels, The Johannine Gospel in Gnostic Exegesis: Heracleon's Commentary on John (Nashville, 
(102) . . . he [Heracleon] also understands "all things were made through him" idiosyncratically when he says, "The one who provided the creator with the cause for making the world, that is the Word, is not the one 'from whom,' or 'by whom,' but the one 'through whom'," taking what

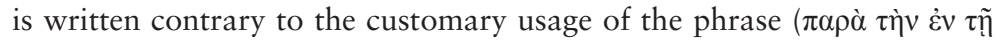

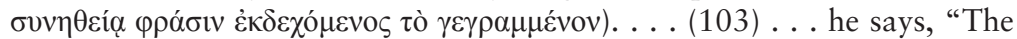
Word himself did not create as though under the impulse of another, that the phrase, 'through him,' should be understood in this way, but another created under his impulse." 34

Origen disputes Heracleon's reading, and reveals that his target commented in a manner with which we are already familiar. Heracleon used John's "through whom" to import a portion of his myth, that the Word was not itself creator, but only the one who ordered others to create. This practice is nicely paralleled in an earlier section of the quotation when Origen tells us that Heracleon glossed "without him nothing was made" with "nothing of the things in the cosmos and the creation."

In fragment 10, commenting on John 1.29 ( "The next day he saw Jesus coming toward him, and said, 'Behold, the Lamb of God, who takes away the sin of the world!'”), we read:

John spoke the words, "Lamb of God" as a prophet, but the words, "who takes away the sin of the world" as more than a prophet ( $\dot{\varsigma} \varsigma \rho \circ \varphi^{\prime} \tau \eta \varsigma$

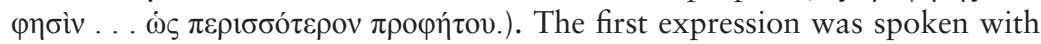
reference to his body, the second with reference to Him who was in that

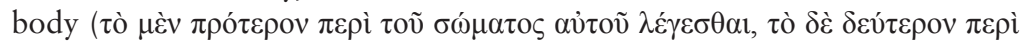
$\tau$ ov $\dot{\varepsilon} v \tau \tilde{\omega} \sigma \omega \dot{\mu} \mu \tau \tau$.). The lamb is an imperfect member of the genus of sheep

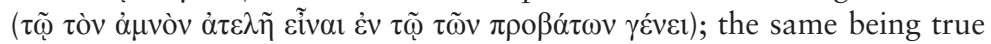
of the body as compared with the one that dwells in it. Had he meant to attribute perfection to the body he would have spoken of a ram about to be sacrificed. ${ }^{35}$

Here Heracleon deploys a common ancient literary-critical concern to identify who is speaking (or spoken about) in a particular text. ${ }^{36}$ In this

TN: Abingdon, 1973); Harold W. Attridge, "Heracleon and John: Reassessment of an Early Christian Hermeneutical Debate," in Essays on John and Hebrews (Tübingen: Mohr Siebeck, 2009), 193-207.

34. Heracleon, frg. 1 = Origen, Jo. 2.14. 100-103 (SC 120:270-74; trans. Heine, 120-21). See Wucherpfennig, Heracleon, 109-60.

35. Heracleon, frg. 10 = Origen, Jo. 6.60. 306-7 (SC 157:364-66; tr. Heine, 252). See Wucherpfennig, Heracleon, 216-18.

36. One of the best introductions to the ancient practice of prosopological exegesis is that of Neuschäfer, Origenes als Philologe, 1:263-76 (and notes at 2:475-81). The application of this technique specifically to the Psalms is given extensive discussion 
case, dividing John's words by claiming that they speak about two different subjects in Christ, the body and the one who was in that body. At the same time, Heracleon also provides us with a lovely example of the manner in which expert literary opinion could be invoked to found an interpretive case on word usage. The use of "lamb" indicates the imperfection of Christ's body, because learned opinion relegates "lamb" as imperfect. This claim to expert knowledge of meaning, and hence ability in spotting the presence of hidden meaning, is nicely paralleled by Origen's own repeated claim in the first fragment I quoted that Heracleon does not interpret terms in a manner consistent with linguistic custom.

While these two texts showcase Heracleon's use of ancient literarycritical reading practices, they need to be complemented with reference to others that demonstrate that he also took a wide variety of scriptural passages as enigmatic. Thus, for example, in commenting on John 2.12, he argues etymologically that Christ going "down" to Capernaum refers to Christ descending to the material and to him alien world. Fragment 12 offers an extensive allegorical treatment of Christ's ascent to Jerusalem and the temple, a fragment which must be placed alongside the extensive allegorical treatment of John 4.46-53 (the healing of the child in Capernaum) in fragment 40.

While this style of exegesis is most extensively witnessed to by the two commentary texts I have considered so far, a few other witnesses to the Valentinian use of these literary-critical practices survive and help us to locate the texts we have examined as most likely a product of a different generation of thinkers than Valentinus himself. Ptolemy's Letter to Flora is

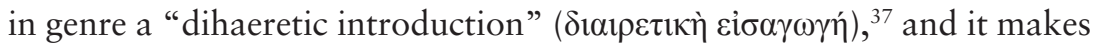
use of a number of literary-critical techniques to make its points. Close textual analysis of the "Savior's words" is presented as the one reliable and appropriate manner in which one may achieve proof and a grasp of the truth. ${ }^{38}$ Ptolemy's arguments in this vein are careful and ingenious. For example, he seems to quote a source very close to Matt 15.3-6 to show Jesus criticizing "the elders" for upholding "their tradition" rather than God's law. He then parallels with this Isaiah 29.13's claim that "this

in M.-J. Rondeau, Les commentaires patristiques du Psautier. Vol. 2, Exégèse prosopologique et thèologie (Rome: Pont. Institutum Studiorum Orientalium, 1985).

37. Here I follow the analysis of Christoph Markschies, "New Research on Ptolemaeus Gnosticus," Zeitschrift für antikes Christentum 4 (2000): 225-54 and Winrich Löhr, "La doctrine de Dieu dans la Lettre à Flora de Ptolémée," Études Théologiques et Religieuses 70 (1995): 177-95.

38. Ep. Flor. 33.3.8. 
people ... [teaches] as doctrines the precepts of men.” In Matt 15.3-6 itself it is this text from Isaiah that Jesus quotes. ${ }^{39}$ At the same time, Ptolemy attempts to strengthen his argument by arguing that Moses's state-

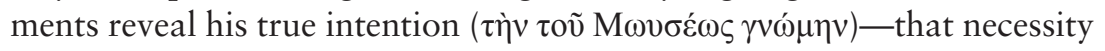
forced him to craft laws suitable for a people unable to obey God's own precepts. ${ }^{40}$ Once again, we meet the ancient literary concern to present a particular reading as reflecting appropriate action on the part of the original author. In a similar vein, Clement's Excerpta ex Theodotu provides us with some evidence that Theodotus (and possible other writers Clement has included in his florilegium) made use of literary-critical practices, although not with any great technical precision. ${ }^{41}$

I have focused in this essay on Valentinian exegetes, and it is they who seem to have been the most sophisticated practitioners and those who provoked the most extensive response; nevertheless, we know of at least a few others who engaged in similar, if probably less sophisticated exegesis. Eusebius famously reports the activities of Theodotus the Cobbler and his disciples, quoting a passage that alleges the use of syllogistic reasoning in exegesis (under the probable influence of Galen) and seems also to suggest they undertook textual emendation. ${ }^{42}$ Epiphanius, however, seems to have possessed an independent witness to Theodotus's exegesis, and his summary shows evidence of Theodotus using close textual analysis of prepositions and word order that directly parallels some of the Valentinian practices examined above. ${ }^{43}$ Theodotus and his disciples were active in Rome during and after the 190s, and thus this evidence shows only that a wide range of groups quickly adopted some of the same practices. Hippolytus gives us notice of two sects among those whom he overall terms "Ophites," the Naassenes and Peratae. These groups not only read New Testament texts as enigmatic, but Homer and a wide range of New Testament texts. We have no extensive passages from which to judge their

39. Ep. Flor. 33.4.11-13. Cf. the close reading of Paul's injunction in 1 Cor 5 at 33.5.15.

40. Ep. Flor. 33.4.6-10 (here, SC 242:56).

41. The passages which seem to reveal a closer use of the scriptural text are not by Theodotus, eg. Exc. 51, 59-62; elsewhere Clement quotes or summarizes passages in which texts are offered as proof but not directly analyzed, eg. Exc. 80. Nevertheless, the possibility that Clement's "quotations" summarize renders any certain judgment impossible.

42. Eusebius, Eccl. Hist. 5.28; cf. Hipploytus, Ref. 7.35-6. For the Theodotians see Peter Lampe, From Paul to Valentinus. Christians at Rome in the First Two Centuries, trans. Michael Steinhauser (Minneapolis, MN: Fortress Press), 344-48.

43. Epiphanius, Pan. 54.1.8-6.4. 
exegetical technique, but enough to see that their manner of treating the New Testament closely parallels the texts we have been examining. Interestingly, Hippolytus even accuses them of inventing a "new grammatical art" because of their supposed inability to recognize which texts are and are not parabolic. ${ }^{44}$ Clear evidence of authors prior to those we have considered so far using such literary-critical techniques is hard to find; Justin, Tatian and Papias are considered at the end of the next section, the only other is provided by Marcion's use of syllogistic reasoning and text-critical techniques (along with the work of his students Apelles and Lucanus). ${ }^{45}$

It is striking that neither Valentinus (fl. c.140-c.170) nor Basilides (fl. c.120-140) seem to have produced texts utilizing the close literary analysis I have explored thus far. The surviving fragments show both authors commenting in a manner that to some extent parallels styles used in second century philosophical commentary. Particular texts-including texts taken from material that would be incorporated into the New Testament-are the subject of extended and somewhat free flowing reflection. ${ }^{46}$ While this observation further helps to make clear the distinctiveness of those Val-

44. See Hippolytus, Ref. 5.8.1 (Miroslav Marcovich, ed., Hippolytus Refutatio Omnium Haeresium, Patristische Texte und Studien 25 [Berlin: de Gruyter, 1986],

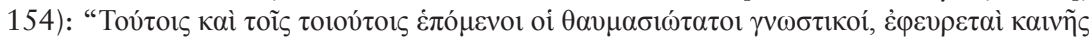

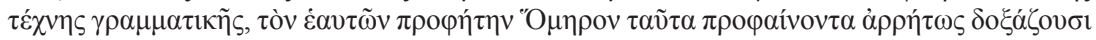

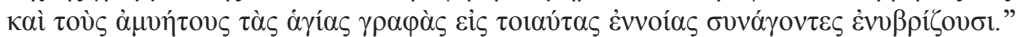

45. For introduction to and relevant literature about Marcion see Barbara Aland, “Marcion (ca. 85-160)/Marcioniten,” Theologische Realenzyklopädie 22:89-101. For Apelles and Lucanus see Lampe, From Paul to Valentinus, 414-16.

46. For Basilides' exegetical technique see Winrich Löhr, Basilides Und Seine Schule: Eine Studie zur Theologie- und Kirchengeschichte des zweiten Jahrhunderts (Tubingen: J. C. B. Mohr, 1996). The title of his Exegetica requires careful consideration. Völker's famous second fragment, the longest of those that survive, offers no exegesis of particular texts. Job 14.4 is quoted at the end of the piece as a proof demonstrating that all human beings are unclean, and there is an allusion to Matt 5.27-28 earlier, but it is the thought rather than the text that Basilides repeats. Fragment 3 consists in a suggestion that Romans 7:9 "I was once alive apart from the law" means that Paul was previously reincarnated as an animal or bird not subject to the law. No other scriptural text is cited to argue for the possibility of a re-incarnationist reading. The fragment is very short and in context may well have contained such scriptural evidence; but as it stands it is certainly compatible with the other fragments, suggesting a more free-flowing philosophical style commentary. In the case of Valentinus, frg. 2, offers a fairly long explanation of Matt 19.17's "one there is who is good," but the biblical text is the point of departure for a free flowing exposition that quotes no other biblical text nor analyzes the text that is quoted directly. The use of Ex 33.20 in frg. 4 may indicate a similar procedure. Contemporary philosophical parallels may be found in Alexander of Aphrodisias and Aspasius. For Valentinus see especially Christoph Markschies, Valentinus Gnosticus? Untersuchungen zur Valentinianischen Gnosis mit einem Kommentar zu den Fragmenten Valentinus (Tübingen: J. C. B. Mohr, 1992). 
entinian texts that have been our focus so far, does it help to date them as the products of a second generation of Valentinians? Valentinus's teaching activity in Rome probably covered around fifteen years between c.136 and c. $166 .{ }^{47}$ Ptolemy's Letter to Flora may perhaps be dated sometime between 145 and $160 .{ }^{48}$ Thus the different styles of exegesis apparent between these works may well have co-existed within the Valentinian community. And so, while (on the basis of analysis of the relationship between their mythologies and those in the fragments of Valentinus ${ }^{49}$ ) it seems most plausible that the commentary quoted by Irenaeus and that of Heracleon represent the work of a younger generation of Valentinians, we cannot say for certain that they did not write while their master was still in Rome, and hence I do not think these texts cannot be dated any more precisely than between c. 150 to c. 180 . One might also suggest that the mere fact of commenting in this detailed fashion on a text reflects a view of that text's status as one whose very vocabulary and word order reveals; such a view seems, at the very least, most likely during a period during which those texts were taking on this status in the broader Christian community. Nevertheless, however we conceive of them endorsing or promoting a unified canon of Christian texts, and an emphasis on close textual analysis of those texts, the Valentinian attempt to harness the capital of ancient techniques of literary analysis to their vision of Christian interpretation suggested a vision of the scriptural text as enigmatic and of the skilled interpreter that could not but be recognized by those at all knowledgeable about debates in ancient literary theory. How would those who opposed Valentinian exegetes respond-would they reject the heritage of ancient literary-critical practice, or endorse (or adapt) another aspect of that complex tradition?

\section{READING THE “PLAIN GOSPEL”}

Over the past few decades, discussion of Irenaeus's exegesis in the Adversus Haereses has focused on a consistent set of themes. The relationship between the regula veritatis and Irenaeus's sense of a unitary scriptural

47. Based on Irenaeus's report that Valentinus arrived during the time of Pope Hyginus and stayed until the time of Anicetus (possibly leaving Rome, like Galen, during the plague of 166 C.E.). See Adv. Haer. 3.4.3.

48. But such a date depends on the argument that the Ptolemy who authored the letter is the same as the Christian teacher of Justin, Apol. 2.2. For this argument see most recently, Lampe, From Paul to Valentinus, 239-40. Against see the persuasive discussion of Christoph Markschies, "New Research," 246-53.

49. See, eg. The discussion of Markschies, "Valentinian Gnosticism." 
text, and some important pieces of his rhetorical/grammatical terminology (especially his use of ' $v \pi$ ó $\theta \varepsilon \sigma \iota \varsigma$ ) have received comment. ${ }^{50}$ His comments in Book 1 on the importance of reading Homeric quotations in context, ${ }^{51}$ and his use of $\alpha v \alpha \kappa \varepsilon \varphi \alpha \lambda \alpha i ́ \omega \sigma ı \varsigma$ as an argument for the unity of the scriptural canon have also been frequently discussed. ${ }^{52}$ But scholars have offered no extended comment on the manner in which he attempts to harness the cultural capital of ancient literary technique to show that his exegetical practice reflects good interpretive practice more generally. The well trained reader, Irenaeus is arguing, should recognize the Valentinian exegetes as exegetical hacks who do not understand their craft. Not surprisingly, in order to make this argument Irenaeus deploys an anti-allegorical rhetoric that locates him within the long history of contesting the most appropriate use of ancient literary-critical techniques, a history we explored briefly in the last section of the paper. ${ }^{53}$

To draw out this feature of Irenaeus's argument I want to examine the reading techniques he deploys in Books 2-3. I focus on this section of the work not simply because considering just one section makes clear the sheer density of the practices that are my concern, but also because these two books make clear the centrality of these practices to Irenaeus's most basic conception of the work: Book 2 was conceived as a refutation of the "heretical" doctrines described in Book 1, while Book 3 is offered as a complementary set of proofs from Scripture.

50. E.g. Adv. Haer. 1.8.1 (SC 264:112).

51. Adv. Haer. 1.9 (SC 264:136).

52. To put the matter in other terms, there is no equivalent in Irenaean scholarship to Neuschäfer's Origenes als Philologe! From existing scholarship see esp. Alain Le Boulluec, La notion d'hérésie dans la literature grecque $I I^{e}-I I I^{e}$ siècles (Paris: Etudes Augustiniennes, 1985) 1:215-53; J. Fantino, La théologie d'Irénée: lecture des Écritures en réponse à l'exégèse gnostique; une approche trinitaire (Paris: Éditions du Cerf, 1994); Philippe Bacq, De l'ancienne à la nouvelle Alliance selon S. Irénée: unité du livre IV de l'Adversus haereses (Paris: Presses universitaires de Namur, 1978); B. Reynders, "La polémique de saint Irénée: Méthode et principes," Recherches de théologie ancienne et médiévale 7 (1935): 5-27; P. Ferlay, "Irénée de Lyon exégète du quatrième évangile,» NRT 106 (1984), 222-34; Y.-M. Blanchard, Aux sources du canon, le témoignage d'Irénée (Paris: Éditions du Cerf, 1993); Rolf Noormann, Irenäus als Paulusinterpret: zur Rezeption und Wirkung der paulinischen und deuteropaulinischen Briefe im Werk des Irenäus von Lyon (Tübingen: J. C. B. Mohr, 1994). Each of these pieces offers some very helpful analysis, but none offers detailed attempt at locating Irenaeus's reading practices within ancient literary-critical traditions.

53. My emphasis on Irenaeus's use of an anti-allegorical rhetoric of scriptural clarity should not at all be taken to mean that I am denying that he also makes use of various techniques of allegorical reading. As I note at more length toward the end of the essay, it is rather that the employment of such a rhetoric pushes Irenaeus toward certain ways of justifying such non-literal reading practices. 
I begin by noting the consistency with which Irenaeus appeals to the scriptural message as pavepóc. At Adv. Haer. 2.27, in a section that William Schoedel described as a "small tractate on theological method," ${ }^{54}$ Irenaeus argues that the entire Scripture (universae scripturae) can be understood "directly and unambiguously" (aperte et sine ambiguitate) by all, even by those who do not believe, as long as one follows "the method of discovery" (disciplinam inventionis). ${ }^{55} \mathrm{~A}$ few sentences previously Irenaeus has told us that one of sound mind will meditate upon those things which God has placed in our power to understand, "these are those which are before our eyes, and which openly and without ambiguity are given in the scriptures." ${ }^{56}$ Schoedel's exploration of the passage shows Irenaeus to be indebted to empiricist traditions particularly well represented in Galen, but it is important that we see how Irenaeus has also co-opted these traditions into a wider discourse of textual clarity.

Thus, the same language occurs in many other passages, but unaccompanied by the broader empiricist language that may be traced in this passage of Book 2. Earlier in the same book, railing against Valentinian use of the parabolic, Irenaeus insists the question of how many Gods there are can only be solved by attention to what is "manifest, consistent and clear" (ex manifestis et consonantibus et claris) in the text. ${ }^{57}$ In Book 3, to take a further example, Irenaeus treats Peter's preaching that Christ fulfils the prophets in Acts 3 as an example of the "plain gospel" (

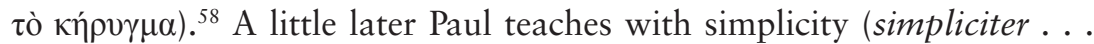
docuit), making himself manifest/clear to all who heard him (ipse facit manifestum). ${ }^{59}$

54. William R. Schoedel, "Theological Method in Irenaeus (Adversus Haereses 2.25-28)," JTS 35 (1984): 31-49. Schoedel rightly draws attention to the presence in Irenaeus of themes from ancient empirical traditions, and perhaps from medical writers-on which see now also Michael Frede, "The Ancient Empiricists," in Essays in Ancient Philosophy (Minneapolis: University of Minnesosta Press, 1987), 243-60but fails to note that in so doing Irenaeus also nicely demonstrates the foundational quality of grammatical practices for a variety of higher disciplines. The same relationship may later be noted with reference to Clement's use of dialectic.

55. Adv. Haer. 2.27.2 (SC 294:266).

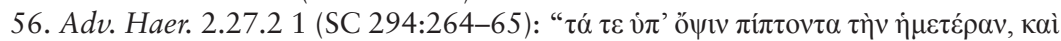

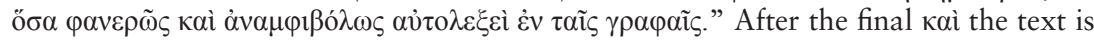
subject to some dispute. I follow the reading of Rousseau and Doutreleau, see SC 293: 307-8 for discussion.

57. Adv. Haer. 2.10.1 (SC 294:88). Cf. the accusation at 2.21.2 that Hesiod provides a "plain" statement of what the "Gnostics" take to be a great mystery.

58. Adv. Haer. 3.12.3 (SC 211:190). The Greek is from frg. 15.

59. Adv. Haer. 3.14.2 (SC 211:260-62). 
If we are to understand these constant claims about the "manifest" meaning of the text, we need to look to the techniques Irenaeus uses to identify that "manifest" meaning. Irenaeus responds to Valentinian exegesis not by ignoring their attempt to claim the cultural capital of ancient criticism, but by claiming it for himself. Close attention to the idiosyncrasies of an author's style, and to the basic ancient question of how one punctuates a sentence are evident throughout Books 2 and 3, as is the technique of explaining seeming anomaly, oddity or inappropriateness in the light of an understanding of the author's purpose or character. Adv. Haer. 3.7 offers an excellent example of these techniques in combination, treating Gnostic reading of Paul's reference to "the God of this world" at 2 Cor 4.4. Irenaeus tells us that he will refute his opponents from Paul himself (ex ipso Paulo ostendemus).$^{60} \mathrm{He}$ argues that Paul did not speak of the God of this world in opposition to any other God, and he does so by means of two arguments. First, one needs to know that Paul frequently transposes word order, Irenaeus provides parallels from elsewhere in Paul's corpus, and names this as the literary figure hyperbaton. ${ }^{61}$ Second, Irenaeus suggests that the smart reader who understands Paul's mode of writing would know that this should be reflected when reading the text aloud, placing pauses so as to reflect the sense- and here we see reflected some of the most basic teaching of the grammarian. ${ }^{62}$ The argument is further bolstered by the claim that Paul writes in this fashion because of the pressures he faced and because of the Spirit impelling him along; when one understands the nature of Paul's career his mode of writing is "appropriate." The "manifest" meaning of the text is discovered by one who believes that interpretation proceeds in the light of a knowledge of an author's life, and their patterns of expression. Indeed, such knowledge is necessary for the basic task of reading aloud the very words. Such attention, Irenaeus implies, provides a sufficient and convincing explanation without resort to the claim that another myth underlies the surface of the text.

Looking more widely in Books 2 and 3, we find Irenaeus claiming expertise in the interpretation of a number of other textual features of interest to the ancient literary critic. In Book 2, for example, Irenaeus ridicules his opponents' reliance on etymology and number symbolism, suggesting that their use of such methods relies on inattention to what is stated "plainly."

60. Adv. Haer. 3.7.1 (SC 211:82).

61. For relevant Greek and Latin discussions of hyperbaton see Lausberg, Handbuch, $\$ 716$.

62. Adv. Haer. 3.7.2 (SC 211:86): "Sicut ergo in talibus oportet per lectionem hyperbaton ostendi et consequentem Apostoli seruari sensum. ..." 
In this case, the "plain" is apparent to one who knows how to read the numeric value of letters appropriately. Thus, Irenaeus argues, his opponents interpret the non-Greek name Jesus as a number of six-letter names to which numerical value may be ascribed, which in turn is of symbolic use. But, Irenaeus tells us, the true Greek equivalent of "Jesus" is Soter and this has a different numeric value. ${ }^{63}$ Similar arguments are then also offered in the case of "Christ."

In Book 3 Irenaeus reflects on the name Christ, using different dimensions of the notion of anointing implied in the name "Christ" to help his argument for the identity of the "Son of God" and the "Son of Man" as well as the relationship between Father, Son and Spirit. ${ }^{64}$ In Book 2 Irenaeus argues that the various divine names, when their original Hebrew meanings are grasped, signify the same being, rather than different Gods. ${ }^{65}$ Similarly, Irenaeus comments on the meaning of "mammon" in order undermine his opponents' claim that the name designates a distinct divine being. ${ }^{66}$

In Adv. Haer. 3 Irenaeus draws on one aspect of prosopological exegesis in support of his central claim in that book that only the Father and the Son are named God or Lord. His concern here is not to ask in whose voice a particular text is speaking, but where a text most directly and unambiguously identifies a character. At 3.6.1 Irenaeus presents as a general principle,

Neither, therefore, would the Lord, nor the Holy Spirit, nor the apostles, have ever definitely and absolutely named one who was not God as God, unless he were truly God; nor would they have named any one in his own person (ex sua persona) Lord, except God the Father who rules over all, and His Son who has received from his Father dominion over all creation. . . .67

All others seemingly named God or Lord are only done so with an additional appellation or in such a way that it is clear that they are not really Gods or Lords. Thus, at Psalm 95.5 "the Gods of the nations" are immediately also named "the idols of demons." This second appositional phrase actually names them "in their own person" (ex sua persona). ${ }^{68}$ Similarly Paul, at 1 Cor 8.4-6, "distinguishes" and "separates" (distinxit . . . separavit) God from those only called Gods, and he has confessed the one

63. Adv. Haer. 2.24.2.

64. Adv. Haer. 3.18.3.

65. Adv. Haer. 2.35.3.

66. Adv. Haer. 3.8.1.

67. Adv. Haer. 3.6.1 (SC 211:69).

68. Adv. Haer. 3.6.3. 
Christ "in his own person" (ex sua persona). ${ }^{69}$ In discussing Luke's testimony to this distinction Irenaeus speaks also of the angel Gabriel confessing the God of Israel ex sua persona..$^{70}$ Summing up this identification of only Father and Son as God and Lord, and commenting on Mark 1.1's identification of "Jesus Christ, the Son of God," Irenaeus writes approvingly "the beginning of the Gospel plainly (manifeste) speaks the words of the holy prophets and immediately identifies (praemonstrans) him whom they confessed to be Lord and God. ..." ${ }^{71}$ In each of these examples Irenaeus treats the "plain" text of the Scriptures as the one source for identifying the main characters in the Christian account of God and world. It does so both by textually pointing at a character, and by providing for us a web of parallel texts that we can easily observe.

The rhetoric of a scripture whose meaning is "clear" to an interpreter who understands how to interpret what is said on the "surface" of the text reaches its high point in Irenaeus's presentation of God as a divine author who has composed a text using the very techniques that any expert interpreter should be able to identify. Thus to claim the necessity of understanding a hidden subtext is to fail in the most basic task of understanding the author's intention in composing. Allow me to draw out the manner in which this theme lies at the heart of Irenaeus's famous assertion that there are only four gospels, mirroring the four winds and the four corners of the earth. ${ }^{72}$ My concern is with the wider discussion in Adv. Haer. 3 which these sentences culminate. The section with which we are concerned begins after Irenaeus has brought to a conclusion his initial assertion that the apostolic writers-who wrote filled with the Spirit concerning the gospel they had publically preached-and the church which has guarded the truth invested in it have continuously taught that only the Father and the Son may be truly named God or Lord. ${ }^{73}$ Now that this has been clearly shown (ostendetur manifestius), Irenaeus asserts, it is time to follow the testimony (testimonia) of the Lord's disciples. ${ }^{74}$ His technique is to draw from the witness of each disciple the same basic announcement

69. Adv. Haer. 3.6.5.

70. Adv. Haer. 3.10.1, and again at 3.10.5.

71. Adv. Haer. 3.10.6 (SC 211:136). A slightly different use of prosopological exegesis is found when Irenaeus emphasizes that the distinction to which he has drawn attention is never compromised even by Christ "in his own person" (3.9.1). Cf 5.25.2 of Paul.

72. Adv. Haer. 3.11.8.

73. Adv. Haer. 3. praef. 3.8.3. The imagery of the disciples investing their teaching in the church is at 3.2.1.

74. Adv. Haer. 3.9.1 (SC 211:98). 
that Christ fulfills the prophets, and was sent by the one God confessed by the prophets in order to redeem. ${ }^{75}$ In some cases Irenaeus points to fairly direct parallel statements. In many other cases Irenaeus brings into alignment texts in order to show that they mutually illuminate. His goal is not best understood as showing how obscure texts may be interpreted by those which are clearer, but as showing that the clear statements of a given disciple mutually illuminate to reveal one narrative, and that one narrative is shared among the disciples.

Irenaeus begins his performance with Matthew, commenting on John the Baptist's preaching and Jesus' baptism in Matt 3, with reference back to the angel's announcement to Joseph in Matt 1. The Baptist announces that God will bring forth living children from the dead stones of Israel and that Christ is the one announced by the prophets (quoting Matt 3.3 and 7). There is, Irenaeus concludes, one God, the Father of the Word, our Lord, who promised that the Word would become incarnate in order that the King (the Father) would become clear (manifestus) to all-echoing Matt 3.3's "and all flesh shall see the salvation of God."76 Irenaeus then turns to Matt 1.20, "the angel of the Lord appeared to Moses in sleep." Matthew himself interprets for us which Lord is meant here (cuius Domini, ipse interpretatur) by speaking at Matt 2.15 of the "Lord" and his "Son," by speaking of Emmanuel being born (at Matt 1.23), and by telling us directly that Emmanuel "is to be interpreted as "God with us" (est interpretatum Nobiscum Deus). ${ }^{77}$ The final elements in this composite are provided by asserting that David also speaks of Emmanuel. Psalm 131.10-11's address to Israel "of the fruit of your body I will place on my seat" is paralleled with Psalm 75.2-3's "In Judea God has been made known ... and his dwelling has come to be in Zion." Having asserted that Matthew already sees the prophets fulfilled by the appearance of "God with us," the visible "salvation of God," Irenaeus can use prophecy to culminate his reading of Matthew; the prophet David can now be

75. I use "disciple" here to reflect Irenaeus's own usage. Irenaeus does not present his focus as the particular texts of the "New Testament," but the disciples who write them or speak within them. Thus, for example, we see him make use of the testimony of Philip, Peter and Stephen from within Acts, but he does not speak of Acts itself as a witness.

76. Adv. Haer. 3.9.1 (SC 211:102). For an excellent description of the various ways in which Matthew is used in Adv. Haer. 3 (though without comment on the literarycritical and rhetorical background of the reading practices used), see D. Jeffrey Bingham, Irenaeus's Use of Matthew's Gospel in Adversus Haereses (Louvain: Peeters, 1998), ch. 2.

77. Adv. Haer. 3.9.2 (SC 211:104). 
adduced to show that he saw the one who was to come as God "dwelling in" Israel and born from the human line of David, "the fruit of David's womb, that is, from David as virgin, and Emmanuel." "78 Irenaeus does not tell us that any of these texts is enigmatic, rather he offers us a series of mutually reinforcing references to the same narrative whose interconnections are signaled by common patterns of reference.

Irenaeus now moves to Luke and Mark. His technique is not simply to find clear parallel statements to the passages he has highlighted in Matthew, but to quote passages from the Gospel's beginning that announce the coming of Christ (perhaps understood as initial announcement of the text's plot) and then to show how surrounding material clearly identifies the key characters of the story (Father and Son), and does so in a manner that meshes with the narrative already drawn from Matthew. Thus Irenaeus turns to Luke's own somewhat abrupt beginning, with the Angels' announcement to Zachariah. Quoting the latter's entrance into the "temple of the Lord" (Luke 1.9) Irenaeus reminds us that this is the Lord whose angel is Gabriel, the one who stands in the Lord's presence (alluding to Luke 1.19). This is the angel who had confessed as God "in his own person" the one who chose Jerusalem and the priestly office-Irenaeus refers back here to his own earlier analyses of Gabriel's confession. ${ }^{79}$ Gabriel tells Zechariah that his son John will be great "in the sight of the Lord;" Irenaeus asks "what Lord?" and for an answer refers us to Jesus' own statement at Matt 11.10 (Jesus himself quoting Mal 3.1). Christ must be the Lord in whose sight John will be made great because it is Christ who identifies John as the forerunner, as the one who prepares the people. Similarly, Irenaeus turns to Gabriel's announcement to Mary at Luke 1.32-33. In response to Gabriel's "He shall reign over the house of Jacob for ever," Irenaeus asks rhetorically "who else is there who can reign uninterruptedly over the house of Jacob for ever, except Jesus Christ our Lord, the Son of the Most High God. . . ?" The response of Mary is then quoted to emphasize that these events involve God "my saviour" taking up "his child Israel ... as he spoke to our fathers." Toward the end of his discussion of Luke, Irenaeus references in short order a list of other texts that identify the giver of the law as Lord and God and as the one who sends his Son to redeem. ${ }^{80}$

Mark is treated only briefly here by commenting on the beginning and end of his text (conscriptio). The beginning obviously (manifeste) quotes the prophets, Irenaeus tells us, and identifies (praemonstrans) the one

78. Adv. Haer. 3.9.2 (SC 211:104).

79. Cf. eg. Adv. Haer. 3.9.2.

80. Adv. Haer. 3.10.4. 
whom they confessed to be Lord and God. ${ }^{81}$ Irenaeus presents Mark 16.19's ". . . he was taken up into heaven and sits on the right hand of God" as a confirmation of the prophecy of Psalm 109.1 (110.1), "The Lord said to my Lord, sit at my right hand": the Lord and God of Psalm 109.1 must be the same as that of Mark 16.19. Between these two brief comments Irenaeus refers us to his discussion in Book 2 of the various aspects and names under which the one God is identified.

Irenaeus's treatment of John's gospel is somewhat different, possessing the tone of a peroration: the strength of the argument is assumed and proof can be more cursory. Irenaeus asserts at the commencement of his discussion that John was written against Cerinthus; hence the first verses name so directly the one Father and his one Word. The "all things" of John 1.3 certainly does not refer to the pleroma; Irenaeus points to John 1.10's insistence that "the world" was made through him as proof that "all things" includes the world. John 1.14's "the Word was made flesh and dwelt among us" is directly aimed against all "Gnostic" readings of the incarnation. So that we need not ask from which or by which God the Word was made flesh John 1.6 tells us "there was a man sent from God ... who came as a witness. ..." Irenaeus asks rhetorically "by what God was the forerunner sent?" and, in answer, rehearses a number of the other verses he has already used that answer this question. It was the God from whom Gabriel brought glad tidings of the Son's birth, the God who promised to send a messenger to prepare the way, the one who bears witness in the spirit and power of Elijah-and Elijah confesses himself servant of the God who made heaven and earth. ${ }^{82}$

“These, then, are the first principles (principia) of the Gospel," Irenaeus announces, and then he summarizes: there is one God who made the universe, was announced by the prophets, gave the law, and who was the Father of Christ. ${ }^{83}$ Only after identifying these principia does Irenaeus turn to his famous assertion that the gospel necessarily has a four-fold form

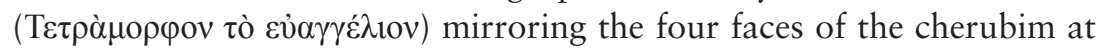
Ezekiel 1.6. The four form a set of images of the works of the Son of God

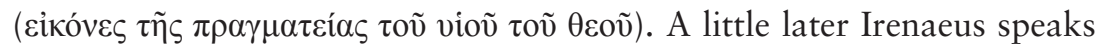

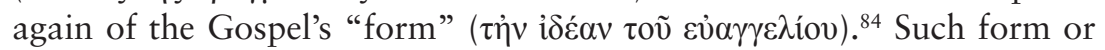

81. Adv. Haer. 3.10.6.

82. The scriptural reference in this last case is unclear, see the note at SC 210:281.

83. Adv. Haer. 3.11.7 (SC 211:158) same term at 3.11.9 line 17.

84. For the first two phrases see Adv. Haer. 3.11.8 (SC 211:162-63), for the third 3.11.9 (SC 211:170). In this case we are lucky to be able to draw on the vocabulary preserved in the 11th of the Greek fragments. This particular fragment, however, has 
shape is the result of divine ordering: “. . since God had made all things proportionate and harmonious, it was fitting that the form of the Gospel would also be pleasingly constructed and elegantly fitted together." ${ }^{85}$ Irenaeus's argument is, I suggest, not focused on arguing that there are four gospels, but that the four are an acceptable set because they exhibit a compatible consonance, one shaped by a divine author who clearly understands well the rules of appropriate composition. ${ }^{86}$

The discussion that I have offered here, concentrating on Adversus Haereses 2 and 3, has shown that Irenaeus's argument against Valentinian exegesis revolves around the principle that the "manifest" or "clear" text of Scripture provides a unitary and accurate account of the divine, and the divine economy. And yet the "manifest" and "clear" is to be analyzed and understood by the application of a set of ancient literary-critical practices. Irenaeus may not have chosen to write in the form of a commentary, but his attempt to claim the heritage of ancient literary-critical practice shows that he understood very clearly the claim to cultural expertise that the Valentinian production of material in the commentary genre involved.

The final piece in the puzzle fits into place when we see that Irenaeus participates in a well-established anti-allegorical tradition, invoking the language of "clarity," while claiming that a knowledge of literary figures, attention to a writer's character and attention to directly expressed meaning, provides a sufficient foundation for reading texts that provide no overt sign that they are enigmatic. A number of witnesses from the first two centuries of the imperial era offer parallels. In his De audiendis poetis Plutarch suggests we recognize Homer's need to present complex characters and to portray that which is unedifying in the mix; the task of the reader is to seek the appropriately edifying through this necessary complexity. A wholesale allegorical approach is to be avoided because it ignores the

a complex history that results in some uncertainties about Irenaeus's actual language, see the discussion at SC 210:95-124.

85. Adv. Haer. 3.11.9 (SC 211:174): “. . . cum omnia composita et apta Deus fecerit, oportebat et speciem Evangelii bene compositam e bene compaginatam esse."

86. Indeed, we must also note that immediately after this passage he returns to other apostolic witness. At 3.12.11 Irenaeus insists that this is the teaching of all the apostles, which he seeks to verify by reference to the letter sent from the Jerusalem "council" in Acts 15. As the letter itself does not include a statement of faith, Irenaeus ingeniously treats the speeches of Peter and James as such and as implying the existence of only one God and one Son. He then states that before the letter was sent all present gave their consent (3.12.14). The claim, then, is not only about the fourfold Gospel, but about the consonance of all apostolic witnesses. Thus, interestingly, Irenaeus treats the Jerusalem "council" as a doctrine-defining (or confessing) event. 
poet's own presentation of his moral purpose. Homer consistently portrays the defeat of the base and the deceptive, and he constantly provides cues at the beginning of episodes that indicate how we should take what follows and he offers judgments at the end of episodes that similarly make clear his intentions. ${ }^{87}$ The attacks on Stoic allegory Cicero puts into the mouths of Velleius and Cotta in his De natura deorum provide another instance. Cotta, for example, argues that attempts to allegorize the names of Gods are unconvincing rationalizations, and that the myths are simply what they appear. ${ }^{88}$ The fragment of Aelius Donatus's fourth century life of Virgil that survives post dates our period, but it is noteworthy that the author insists the poet should only be read allegorically in small sections that are clearly indicated, because he and Theocritus (whom he sought to imitate) wrote "simply" (simpliciter). Donatus thus shows the persistence of an anti-allegorical rhetoric within the grammatical tradition that seems to have grown directly from its Alexandrian roots. ${ }^{89}$

It is vital to recognize that when I suggest Irenaeus employs an antiallegorical rhetoric, I do not mean to deny that he also presents us with many examples of non-literal exegesis. It is rather the case that Irenaeus's adaptation of these techniques and this rhetoric presents him with a particular task in accounting for the possibility of non-literal reading. Investigating how he proceeds to do so is beyond the scope of this essay, but one brief example may make a little clearer how Irenaeus could use the techniques and rhetoric that we have already seen toward this end. Just before the famous discussion of scriptural clarity at 2.27, Irenaeus criticizes those who link the "twelfth aeon" and Judas, the twelfth apostle, and the passion of Christ (which, they say, happened in the twelfth month). ${ }^{90}$ The

87. Plutarch, aud. poet. 19A-21D. As an example of the manner in which Plu-

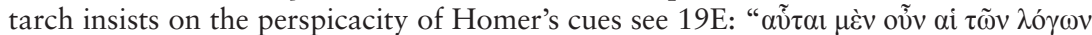

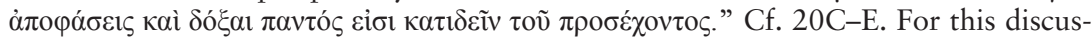
sion and wider critiques of allegory from the period see David Dawson, Allegorical Readers and Cultural Revision in Ancient Alexandria (Berkeley: University of California Press, 1992), 52-72; Pépin, Mythe et allégorie, 132.

88. Cicero, nat. deo. 3.62-63. Seneca's critique of etymological allegory in Ben. 1.3 is in the same vein.

89. Giorgio Brugnol and Fabio Stok, eds., Vitae vergilianae antiquae, Scriptores graeci et latini (Rome: Istituto Polygraphico, 1997), 26.

90. I am grateful to Anthony Briggman for pointing out this example to me. See his Irenaeus of Lyons and the Theology of the Holy Spirit (Oxford: Oxford University Press, 2012), 136-45, for an excellent discussion of harmony in the ordering of the cosmos. It seems likely that harmony as a literary value for Irenaeus finds a ground in Wisdom's ordering of the cosmos (a connection that Irenaeus is by no means alone in making). 
links are drawn improprie et inconsequenter: Judas was not restored to his place as was the twelfth aeon; the passion of Christ is in no way similis to the passion of the twelfth aeon. Indeed, Irenaeus continues, the "twelfth Aeon" is in fact the "thirtieth" and thus there can be no correspondence. The links drawn are "in every respect mutually dissimilar and inharmonious" (per omnia ... dissimile et inconveniens invicem sibi . . .). ${ }^{91}$ Irenaeus does not simply condemn Valentinian non-literal reading per se, he attempts to persuade us that it fails to read the literal level clues that the text offers according to appropriate literary canons. It is not bad because it is allegory, but because it is an example of clumsy and unconvincing reading. The same canons of good reading that justify Irenaeus's anti-allegorical literal exegesis, may thus also govern allegorical reading. A detailed account of how Irenaeus's views on non-literal reading are so governed (and how far this represents an innovation) is beyond the scope of this article, but recognition that it may be so helps to show that an anti-allegorical rhetoric need not imply an author is of necessity opposed to allegory!

\section{INNOVATION AND CONTINUITY IN IRENAEUS'S EXEGESIS}

Before assessing the wider significance of my argument, it is important to spend a little time characterizing Irenaeus's innovation with a little more specificity. In his use of literary-critical practices Irenaeus certainly had one obvious precedent: Justin. It can be fairly supposed that someone with Justin's philosophical knowledge also possessed a good understanding of at least the skills taught by the grammarian and, indeed, he provides us with a number of examples. ${ }^{92}$ But the vast majority of these come from his exegesis of the inherited Jewish Scriptures. He is attentive to genre and trope; a number of times, for example, he suggests that a particular prophetic text is spoken parabolically, and provides evidence from within the text that this is so. ${ }^{93}$ We also find prosopological techniques: at Dial. 42.2 Justin argues that Isa 53.1-2 is spoken "in the person of the Apostles"

91. Adv. Haer. 2.20.1-4 (SC 294:200-204).

92. As with Irenaeus, there is little in existing scholarship that explores in detail his use of literary-critical techniques, though see the useful G. Otranto, "La terminologia esegetica in Giustino," Vetera Christianorum 24 (1987): 23-41.

93. Dial. 36.2. Cf. Dial. 57.2, where we need to be familiar with tropological

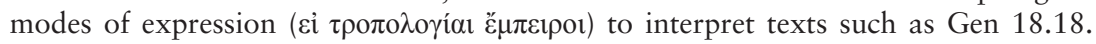
Note also that Trypho objects to Justin's attempt to use Isa 40.1-17 on the grounds

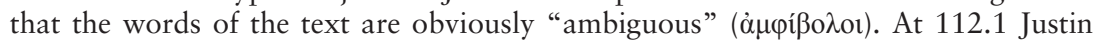
complains about Trypho (and his companions) taking words $\tau \alpha \pi \varepsilon v \tilde{\omega} \tilde{\zeta}$ and not attend-

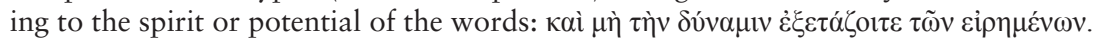




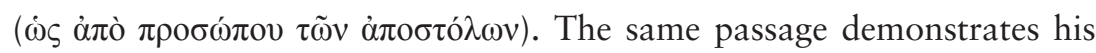
attention to identifying mutually illuminative parallels: he suggests that we interpret Isaiah's "we have preached before him as a little child" by paralleling the singular child with the one body of 1 Cor. $12.12 .{ }^{94} \mathrm{He}$ also sees prosopology as a useful polemical tool. An excellent example is the extensive discussion at Dial. 59-60 that culminates in Justin's account of who speaks from the burning bush at Ex 3.2-4. ${ }^{95}$ Parallel material is to be found in the "first" Apology. ${ }^{96}$ In one passage Justin also turns to an etymological explanation of "Israel" to justify a prophetic interpretation. ${ }^{97}$

Now, in the Dialogue, although Justin does quote some texts from the "memoirs" of the apostles (perhaps via a collection of testimonia), they fulfill a complementary role and are not discussed in detail themselves. In the Apology rather more quotations appear, but here, for the most part, they are either given as examples of Christ's teaching about different topics ${ }^{98}$ or offered as a reliable record of Christ's life and teaching that reveals how perfectly Christ fulfilled Jewish prophecy. ${ }^{99}$ Although Justin speaks many times of “The Prophetic Spirit” ( $\tau$ ó $\pi \rho \circ \varphi \eta \tau$ «òv $\pi v \varepsilon \tilde{u} \mu \alpha$ ) speaking in the Jewish Scriptures, and although the phrase is specifically used to name God's writing of the Scripture so that it might mean far more than the Jews could know, he does not have a parallel phrase to describe God's authorship of the "memoirs" of the apostles.

And yet, this is not quite true. On occasion Justin closely links the Prophetic Spirit and Christ, and once he parallels the Spirit's prophetic utterance with Christ speaking to the same effect. ${ }^{100}$ It is noticeable that when he makes this latter move we find him offering a close literary-critical

94. Dial. 42.2-3 (Philippe Bobichon, Justin Martyr. Dialogue avec Tryphon, Paradosis 47.1-2 [Fribourg: Editions Universitaires Fribourg Suisse, 2003], 286-88).

95. At 60.2 Trypho suggests that in the burning bush there are two, an angel and God; Justin counters that even if there are two, it is not the Creator of all who appears, but the one who appeared to Abraham and Jacob. Then (60.4) he goes on to argue that, in fact, there is only one, who is termed both "angel" and "God." Throughout, the term "person" is absent, but the question of "who speaks?" or "whom does the text identify?" is at issue.

96. See esp. Apol. 36.1-36.3.

97. Dial. 125.1-5.

98. Most notably at Apol. 14.4-17.4.

99. E.g. Apol. 35.1-9, 38.1-8, 48.1-3.

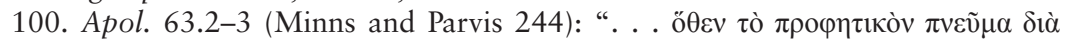

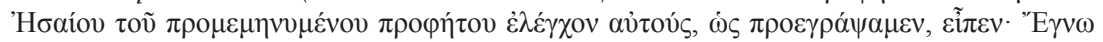

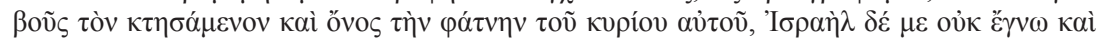

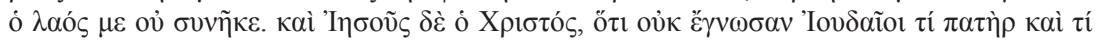

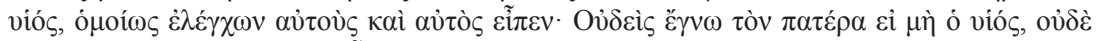

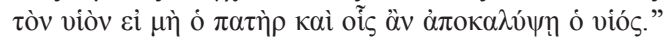


exegesis of the sayings he quotes. ${ }^{101}$ Thus Justin quotes Matt 11.27, "No one knew the Father except the Son or the Son except the Father and those to whom the Son should reveal him." He tells us that the Son is the Logos, as well as "angel" and "apostle"-meaning the one who announces and is sent to reveal—and adds the saying "the one who hears me hears the one who sent me" (a version of Luke 10.16). ${ }^{102}$ Justin then joins to this brief exegesis a series of prophetic texts as a proof ( $\varepsilon \dot{i} \zeta \dot{\alpha} \pi$ ó $\delta \varepsilon 1 \xi i v)$ that Jesus was formerly the Logos who spoke from the pillar of fire and appeared as a bodiless image. The section ends with Justin repeating the parallel between the Prophetic Spirit's announcement of Israel's failure to understand and Jesus's statement that "no one knew the Father. . . ."103 Thus, Justin can, when polemical need demands, treat at least some aspects of the "memoirs" as a textual resource for the very same sort of close analysis that he is prepared to use on the Jewish Scriptures. Lacking his lost works against "heresies" and Marcion, we do not know whether more of the same would have been found there. ${ }^{104}$

Thus, while Justin offers one of the earliest examples of a Christian writer extensively and consciously applying literary-critical reading practices to establish the sense of the text, it seems that he was only beginning to envision the "memoirs" and "sayings" of the Lord as holding the same textual status as the inherited Jewish Scriptures. And so, Irenaeus certainly innovates in the sheer extent to which he deploys literary-critical practices, in the extent to which he makes the use of them as the marker of good exegesis, and in the extent to which he uses them on the texts of the "New Testament." While Irenaeus certainly seems to stand in a trajectory of Christian writers who increasingly treat the Christian Scriptures as appropriately subject to detailed literary-critical analysis if their meaning is to be discerned, Irenaeus's sudden innovation within this trajectory can most plausibly be explained as driven by opposition to Valentinian attempts to harness the cultural capital of ancient literary-criticism to support their particular allegorical styles.

But these clear innovations should not be allowed to mask important continuities between his own exegesis and that of earlier Christian generations. Consider three early texts: Hebrews 1-3, 2 Clement 2-7, and the analysis of Psalm 21(22) at Justin, Dial. 97-106. Each quotes scriptural

101. The only other time Justin offers extended exegesis of anything from the Gospels is at Apol. 61.4ff.

102. See A. J. Bellinzoni, The Sayings of Jesus in the Writings of Justin Martyr (Leiden: Brill, 1967), 20-24.

103. Apol. 63.13.

104. See Eusebius, Eccl. Hist. 4.11. 
lemmata from one or several texts and adds interpretive remarks. In the case of Hebrews and 2 Clement scholars have plausibly suggested that their authors possessed some rhetorical knowledge, but attempts to offer a precise account of the intellectual practice that gave rise to the particular commentary styles exhibited cannot move beyond the more or less probable suggestion. This is so not simply because of gaps in our knowledge of their context; it is also because neither text makes use of any obvious technical terminology, or attempts to claim such terminologies as justification for their readings and both seem to display reading practices that are rather basic compared to those used by more conscious Greek commentators, or by the writers of the Mishnah and later Jewish commentary. ${ }^{105}$ In the case of the third text I noted, Justin has possibly incorporated into his text an earlier discussion of Psalm 21 (22); if this interpretation is correct we should note both that it parallels the first two I noted in its lack of a technical terminology and, importantly, that Justin could incorporate it into his more developed text without obvious disjunction because of the relationship that seems to obtain between the earlier more simple exegetical form and the later more complex form. ${ }^{106}$ Even if this interpretation not be allowed, it remains the case that this passage nicely shows the character of the continuity between the exegesis of the earlier two texts

105. On 2 Clement see Ernst Baasland, "Der Klemensbrief und früchristliche Rhetorik: 'Die ersts christliche Predigt' im Lichet der neueren Forschung," ANRW II.27.1 (1993): 78-157; Karl Donfried, The Setting of Second Clement in Early Christianity (Leiden: Brill, 1974), 34-41, 96-97; Christopher Tuckett, 2 Clement. Introduction, Text and Commentary (Oxford: Oxford University Press, 2012). See also the commentary of Andreas Lindemann, Die Clemensbriefe (Tübingen: J. C. B. Mohr, 1992), 203-21. The literature on Hebrews is, of course vast. However, a good example to illustrate my point is provided by the recent study of Susan E. Docherty, The Use of the Old Testament in Hebrews (Tübingen: J. C. B. Mohr, 2009). Docherty works hard to show parallels between Hebrews and Mishnaic exegesis, using the work of Goldberg and Samely, but cannot not move beyond describing plausible analogies. A further parallel is provided by the relationship between the commentary form(s) found at Qumran and later Rabbinic procedure. On the difficulty of defining the origins of Qumranic practice see for example Daniel A. Machiela, "The Qumran Pesharim as Biblical Commentaries. Historical Context and Lines of Development," Dead Sea Discoveries 19.3 (2012): 313-62.

106. As originally suggested by W. Bousset, Jüdisch-Christlicher Schulbetrieb in Alexandria und Rom. Literarische Untersuchungen zu Philo und Clemens von Alexandria, Justin und Irenäus (Göttingen: Vandenhoeck \& Ruprecht, 1915), 292. My claim here does not necessarily depend on assuming that the authors of these earlier texts knew and but did not use those more complex techniques; the relationship may also result from a common material textual culture, and growth from a common religious root in Jewish traditions of "inner-biblical exegesis." These questions are beyond the scope of the present paper. 
by the mere fact of its similarity to those texts, and its unproblematic presence alongside passages where Justin consciously invokes more complex literary-critical techniques. ${ }^{107}$

In the specific case of his exegesis of "New Testament" texts, one further point may underscore the extent to which Irenaeus's innovation also exhibits continuity. Earlier, I noted Irenaeus's claim at $A d v$. Haer. 3.14 that Paul speaks simpliciter and thus makes himself clear (ipse facit manifestum). In the same paragraph Irenaeus also observes that Paul speaks in the same manner as Luke who "carefully" (diligenter) recorded in writing all the details of his journeys_- "places and cities and numbers of days"-so that we know, by the sheer presence of such detail, that his narrative is true. ${ }^{108}$ There is, then, no basis for accepting or rejecting part of the Lucan narrative: its character forces us to accept it all. ${ }^{109}$ Part of Irenaeus's argument here seems to be that the character of Luke's text shows him to be writing history. Not only does this then suggest the inappropriateness of treating the text as enigmatic, it reveals Irenaeus participating in an older and broader sense that this is the genre of the "gospels." Justin and Tatian seem to have viewed them thus, as did Papias. ${ }^{110}$ Origen shows us that Celsus, probably writing during the latter half of the second century, was of the same opinion. ${ }^{111}$

107. Two caveats are necessary here. First, I have made reference to just three examples of commentary style passages in early texts in order to highlight the differences with both Valentinian exegesis and that of Irenaeus. In a wider study I would hope to show that the same distinction obtains when we look at examples of exegesis that are not commentary-like in form. Second, there is of course much also to be said about the Pauline corpus. However, while Paul makes significant use of rhetorical techniques to convince and persuade, and while he very occasionally offers literarycritical observations, he shows little interest in claiming for himself the cultural capital of close commentary techniques to justify his readings.

108. Adv. Haer. 3.14.2 (SC 211:260-62).

109. Adv. Haer. 3.14.4.

110. My comment on Tatian is based on noting the common concerns in his condemnation of those who allegorize the myths (Or. 21), his technical criticism of Herodotus's historical writing when he inserts myth (cf. Or. 26) and disrupts "an orderly exposition of truth" ( $\dot{\alpha} \lambda \eta \theta \varepsilon i ́ \alpha \varsigma \delta 1 \alpha \kappa o ́ \sigma \mu \eta \sigma \iota \varsigma)$, and in the project of the "Diatesseron" itself if it is conceived as a project in compiling historical sources into a unified account-for

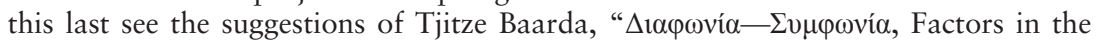
Harmonization of the Gospels, especially in the Diatesseron of Tatian," in Gospel Traditions in the Second Century: Origins and Recensions, Text and Transmission, ed. W. L. Petersen (Notre Dame, IN: University of Notre Dame Press, 1989), 133-54. For Papias see Eusebius, Eccl. Hist. 3.39.1-4 (in a longer discussion, this observation, obviously enough, requires supplementing with a discussion of what Papias might have meant by "exegesis").

111. See c. Cels. 1.20 (Cf. Porphyry, c. Chr. frg. 39). For Origen's extended response see c. Cels. 4. 49-50. 
Irenaeus thus may have shared an assumption with earlier Christian intellectuals; the innovation he effects involves using on those "histories" some of the techniques of analysis that an ancient anti-allegorical critic would have recognized as appropriate, and reading those texts thus as part of an inter-related set of Hebrew and Christian Scriptures. Irenaeus's innovation seems to be both part of a wider shift in the way that these texts were treated and, perhaps, a motivating factor in that shift. In any case, the most plausible explanation for the timing of this shift and the completeness with which it is effected between Justin and Irenaeus is, I suggest, the stimulus provided by the appearance of detailed Valentinian commentary. This stimulus pushed Irenaeus to take the proto-orthodox appropriation of one strand of ancient literary criticism to new levels.

\section{AVENUES FORWARD}

If I am right to see Irenaeus's exegetical practice as both naturally consequent on the increasing engagement of a growing Christianity with the high literary culture of the Roman world, and as stimulated and shaped by the particular controversies over Valentinian exegesis that were so important to him, then it seems to me that two tasks are demanded of us. The first is to ask how far Irenaeus's contemporaries and immediate successors demonstrate similar dynamics; the second is to examine how far these Christian authors simply adopt, and how far they adapt ancient literary techniques to their own ends (by qualifying the techniques or by showing a preference for particular techniques over others).

Although this article represents the first published step in this project, the wider research that I have undertaken provides a wealth of evidence that very similar techniques and rhetoric, and a similar opposition to Valentinian exegesis, shape the exegesis of those one might count as Irenaeus's near contemporaries, figures such as Clement of Alexandria and Tertullian. The former figure is of particular importance (I eventually hope to show) because of the particularly stark way he combines a similar antiallegorical rhetoric with a highly developed allegorical practice. Showing the parallels between Irenaeus, Clement, and Tertullian then raises questions about the place of Origen. Does his well-developed literary-critical practice actually enable us to think of him as in the second generation of those who constitute what I have described as a second "origin" of classical patristic exegesis?

In the second place, how far may we speak of writers such as Irenaeus and Clement adapting, not simply adopting ancient literary-critical practices? In controversy with the particular emphases of Valentinian exegesis, did 
Irenaeus and those who shared his strategy give prominence to a particular set of ancient literary-critical techniques? To take a possible example, Irenaeus seems to show himself unsurprisingly reticent to advance textual criticism (especially claims that material had been interpolated), and he is reticent to make use of other quasi-historical material about Christ to illuminate the gospels. The absence of such arguments from his works is quite understandable, given the hermeneutical vision of those he opposed. But this observation is only to pose a question: what more can be said about which techniques Irenaeus and others adapted against the Valentinians, how far does that set expand over time as the immediate Valentinian threat diminishes, and how far, if such patterns of such adaptation can be traced, can we speak of Christian exegesis after Irenaeus as a distinct subset of ancient literary-critical traditions? How far did the use of these techniques in aid of an exegesis that took the regula veritatis to be measure of the Scriptures also promote the rise to prominence of particular techniques? There is then much to be done, both to test the thesis I have offered, and to explore its possible ramifications.

Among scholars currently writing, Alain Le Boulluec has possibly helped us more than any other to understand the development of Christian heresiology in the second century. In a Festschrift article from 1996 he argues that the notion of a fixed scriptural canon emerges in the context of successive disputes with those whom come to be identified as "heretics." But he suggests that one cannot understand the manner by which Scripture became a norm against the "heretical" without understanding that actually a set of norms gradually emerges: the rule of faith or truth, belief in the apostolic succession, the regularizing of ecclesial structures. This set is the context within which Scripture functions as an anti-heretical rule, and thus the mature discourse of orthodoxy and heresy that we see emerging at the end of the second century is inseparable from the institutional and intellectual culture that emerges from earlier disputes. ${ }^{112}$ With this picture I largely agree, but one vital element is missing from it. The emergence among those who opposed Valentinian exegesis of a common adoption

112. Alain Le Boulluec, "L'écriture comme norme hérésiologique dans les controversies des II et III ${ }^{\mathrm{e}}$ siècles (domaine grec)," in Stimuli. Exegese und ihre Hermeneutik in Antike und Christentum. Festschrift für Ernst Dassmann, JAC Ergänzungsband 23, eds. Georg Schöllgen and Clemens Scholten (Münster: Aschendorffsche, 1996), 66-76, here see especially the conclusion on 76. With this argument one should now combine Christoph Markschies's elegant argument in his Kaiserzeitliche christliche Theologie und ihre Institutionen: Prolegomena zu einer Geschichte der antiken christlichen Theologie (Tübingen: Mohr Siebeck, 2007). 
(and perhaps adaptation) of ancient literary-critical practice was a central element in the Christian community's developing sense of what it meant to be a scriptural community. Just as the emergence of the "rule of faith" would contribute to the gradual development of more precise creedal articulations of the faith, so the exegetical practices developed against the Valentinians during the period between 175 and 200 laid the foundations of the classical patristic exegesis of later centuries, and thus of the very character of the scriptural discussion and polemic that so characterizes later Christian literature.

Lewis Ayres is Professor of Catholic and Historical Theology, University of Durham 